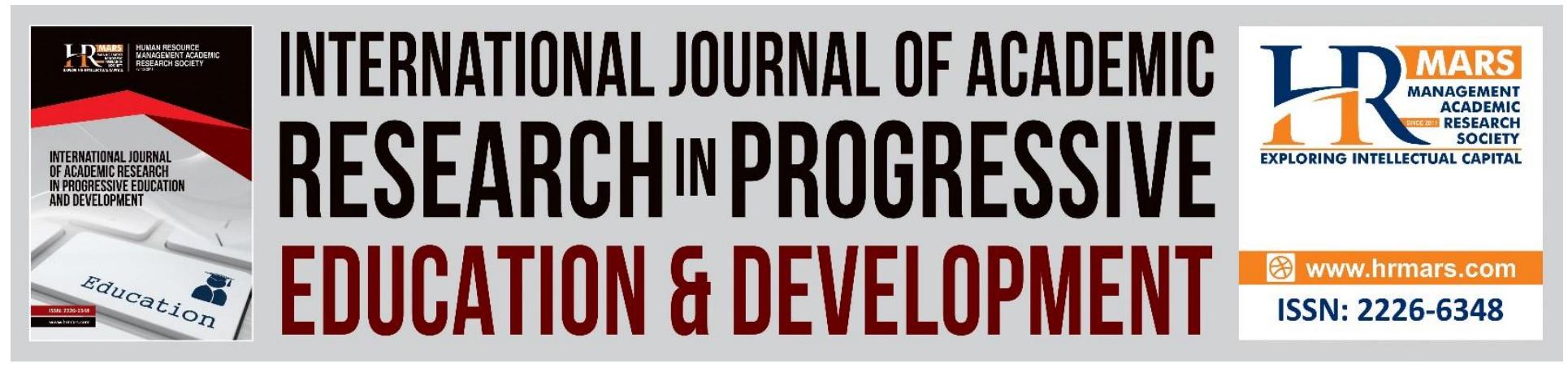

\title{
Digital Citizenship Literacy Knowledge among Undergraduates of Sultan Idris Education University: Preliminary Studies
}

Noor Banu Mahadir, Nur Hidayah Baharudin \& Zuraini Jamil@Osman

To Link this Article: http://dx.doi.org/10.6007/IJARPED/v10-i2/9070

DOI:10.6007/IJARPED/v10-i2/9070

Received: 05 March 2021, Revised: 07 April 2021, Accepted: 27 April 2021

Published Online: 19 May 2021

In-Text Citation: (Mahadir et al., 2021)

To Cite this Article: Mahadir, N. B., Baharudin, N. H., \& Jamil@Osman, Z. (2021). Digital Citizenship Literacy Knowledge among Undergraduates of Sultan Idris Education University: Preliminary Studies. International Journal of Academic Research in Progressive Education and Development, 10(2), 416-434.

Copyright: (C) 2021 The Author(s)

Published by Human Resource Management Academic Research Society (www.hrmars.com)

This article is published under the Creative Commons Attribution (CC BY 4.0) license. Anyone may reproduce, distribute, translate and create derivative works of this article (for both commercial and non-commercial purposes), subject to full attribution to the original publication and authors. The full terms of this license may be seen at: http://creativecommons.org/licences/by/4.0/legalcode

Vol. 10(2) 2021, Pg. 416 - 434

http://hrmars.com/index.php/pages/detail/IJARPED

JOURNAL HOMEPAGE

Full Terms \& Conditions of access and use can be found at

http://hrmars.com/index.php/pages/detail/publication-ethics 


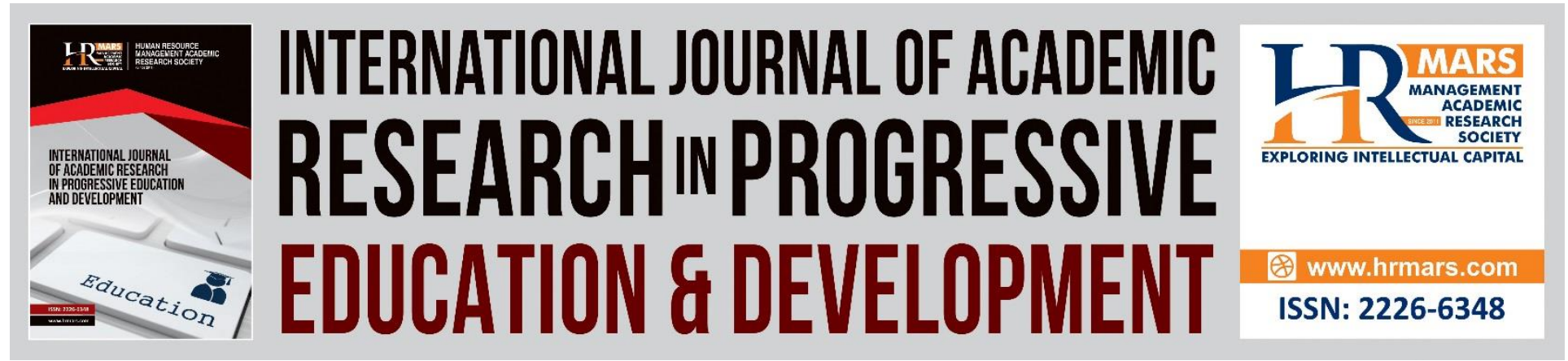

\title{
Digital Citizenship Literacy Knowledge among Undergraduates of Sultan Idris Education University: Preliminary Studies
}

\author{
Noor Banu Mahadir, Nur Hidayah Baharudin \& Zuraini \\ Jamil@Osman \\ Department of Moral, Civics and Character Building Studies Faculty of Human Sciences \\ Universiti Pendidikan Sultan Idris Tanjong Malim, Perak, Malaysia
}

\begin{abstract}
The demand for technology use among students had become inseparable, thus required them to know the importance of digital citizenship. This paper presents a new verified measuring digital citizenship model of knowledge literacy among undergraduates' students at Universiti Pendidikan Sultan Idris, Perak, Malaysia. This article reports the finding of digital citizenship knowledge sub-variables of rights and responsibilities, the technology used, and ethics. The measuring model of Confirmatory Factor Analysis results is (CMIN=727.099, DF=149, CMIN/DF= $4.880, \mathrm{p}=.000, \mathrm{CFI}=.940, \mathrm{GFI}=.927, \mathrm{TLI}=.931, \mathrm{RMSEA}=.062$ ) had achieved the convergent validity. The findings of the study are relevant for evaluating undergraduates' digital citizenship literacy knowledge in Malaysia. It has previously been observed that studies related to digital citizenships has been done in a multidimensional nature of the topic such as digital and media literacy, civic engagement online, rights and responsibility when online and online identity and security. This study aimed of looking at digital citizenship within digital citizenship knowledge in the scope of rights and responsibilities, technology use, and ethics.
\end{abstract}

Keywords: Digital Citizenship, Knowledge, Rights and Responsibilities, Technology, Ethics

\section{Introduction}

The rapid growth of digital technologies positively affects information distribution and accessibility. Technology users, particularly young people, cannot avoid technology abuse. Young people are prone to abuse, discrimination, cybersecurity, and identity theft (VanFossen \& Berson, 2008). It applies to automated social networking platforms that contain too much content and make it difficult to manage (Richards, 2010). Therefore, this situation exposes teenagers to feelings and physiological risks (Oxley, 2011) (Abdulrahman, 2015). As knowledge gives the true meaning of trust (Darwin, 2003), knowledge bases start with information acquired from individual readings, interactions, and observations. Knowledge is the ability to learn, maintain, 
and use a wide range of knowledge, including understanding, abilities, wisdom, and experience (Ibrahim, 1995). Thus, knowledge mastery includes two fundamental concepts, namely the understanding of an entity that is viewed as a whole, affecting thinking capacity.

Knowledge building is an essential construct because knowledge is based on how the natural system works and interacts with them. Active digital citizenship fosters students to practice ethical behavior (Tan, 2011) through an integrated curriculum in nine areas: access, trade, communication, literacy, ethics, law, rights and responsibilities, health and well-being, safety (Ribble \& Bailey, 2007). Countries like New Zealand and Australia seek to encourage and emphasize the value of digital citizenship's rights and responsibilities. They are attempting to make it part of government policies (Manzuoli, Sánchez, \& Bedoya, 2019). This situation indirectly demonstrates the need to reinforce digital citizenship knowledge as universal human rights (Simsek \& Simsek, 2013; Gorman, 2015; Sullivan, 2016). Experts supported this initiative in this field, such as Area \& Ribeiro (2012), who clarified that new literacy is an individual right and a necessary condition for social and democratic growth in a 21st-century society.

This study aims to develop an instrument to measure students' digital citizenship level in terms of knowledge, especially digital users' rights and responsibilities. This study's findings will also provide an overview of the knowledge constructs of digital citizenship in Malaysia. Next, instruments that are appropriate to the characteristics in Malaysia can be constructed. Being a good digital citizen is a must for every digital user, regardless of gender, age, race, and more. Therefore, this study's importance is vital in building a digital citizenship knowledge construct for higher education students. The implementation of this study will provide an overview of the need to be a good digital citizen to create awareness of cyberspace issues. Next, this study's benefits will evoke a sense of responsibility to appreciate life as an excellent digital user in society and then apply it in daily life.

\section{Digital Citizenship}

Digital citizenship is defined as a set of appropriate rules and an attitude of accountability using technological tools correctly. Digital citizenship is also defined as a quality required by citizens to use digital tools and behave well in various digital environments (Searson, Hancock, Soheil, \& Shepherd, 2015). Digital citizenship forms a concept related to digital users' things so that technology is used adequately and competently. Another meaning for digital citizenship is managing and monitoring behavior in using technology by taking into account ethical values, norms, culture, and security (Aslamiah, 2015). Digital citizenship is how digital citizens know the best way to use technology (Ohler, 2011). Aslamiah (2015) identifies digital citizenship as a type of regulation or legislation that encompasses responsible conduct in the appropriate use of technological advances. Digital citizenship involves the idea of what users need to learn about using technology ethically and adequately by rights and obligations (Aslamiah, 2015). The concept of digital citizenship is the ability to control and track actions using digital technologies, with a particular focus on factors such as safety standards, ethics, norms, and culture. 
Isman and Gungoren (2014); Ribble \& Bailey (2007) have defined digital citizens as individuals who use technology effectively and competently. Digital citizens refer to individuals who use information technology to communicate with society, politics, and even the government. Mossberger, Tolbert \& McNeal (2011) define a digital citizen as someone who uses the internet regularly and effectively. Internet use was used not only for technical needs but also for educational and growth purposes (Biladeau, 2009; Shal, El Kibbi, Ghamrawi, \& Ghamrawi, 2018). Studies by Bouhnik and Deshen, 2013 show that the internet has affected students as a whole and made them more "digital people" where they have continuous and efficient internet access (Mossberger, Tolbert, \& McNeal, 2011). Nevertheless, technology consumers who are confident using these software devices are unaware of the difficulty and dangers of using those (James et al., 2010). The definition of "Digital Natives" identifies individuals who have adjusted to the opportunity to use digital technologies in human life and through intellectual processes (Bittman, Rutherford, Brown, \& Unsworth, 2011). Most researchers see that technology plays a significant role for students in this modern era and finds them representing digital natives, as they spend more time in digital relationships than in family or school environments (Ghamrawi, 2018). Studies have shown that internet usage affected adolescents' psychological, emotional, and physical growth as they tend to be under control (Orth \& Chen, 2013). It is indicated that international promotion of digital citizenship promotes empathy, thus reinforcing prevailing norms of digital behavior (Gazi, 2016). Nevertheless, this technology does not promote people's direct involvement in which citizens will make decisions, and it includes all segments of the population (Alcaide - Muñoz, Rodríguez - Bolívar, Cobo, \& Herrera - Viedma, 2017; Sampedro, Sánchez, \& Poletti, 2013)

Students who comply with digital technology laws are liable for their online behavior. They need to know what is right and wrong, and even what is right and wrong is involved in online activities (Curran, 2012; Oxley, 2011). Digital users should also be aware of the legal consequences of infringing the relevant rules and regulations. Individuals with knowledge of technology's ethical values will shape a positive and responsible digital culture. Ethics can explain by demonstrating that people online are technologically digital citizens capable of exhibiting acceptable ethics. They stick to the virtual world's customary laws, norms, and standards, where most of them are unwritten. (Hollandsworth, Dowdy, \& Donovan, 2011).

\section{Component of Digital Citizens Knowledge}

Knowledge is essential to be studied in order to shape attitudes and behaviors. Education also plays a vital part in developing active teaching and learning processes. Educators with a strong knowledge base and capability in implementing quality teaching and learning processes will develop excellent students in understanding the information given (Afinde, 2016). According to Richmond \& Morgan (1977), knowledge is an occurrence that has already developed or is subject to conditions. Knowledge of concepts refers to comprehension as well as ideas relevant to authoritative written assistance. The experience of digital people in this study includes perceptions of students of digital rights and responsibilities, the use of new technologies, and student behavior. 
In this digital age, the internet's availability has become a powerful medium because individuals tended to voice their views publicly. Consequently, the internet has become a much more reasonable way of delivering information to the public without boundaries. In Malaysia, governments are making every solution to engage with the adverse effects of the internet. People born with the advent of digital technology were exposed to becoming responsible, obedient, and successful digital citizens. It is essential to be a well-educated and active citizen, but it is complicated by misinformation on internet platforms. Realizing the focus of attention when vast knowledge is available is necessary for educated people (Krutka \& Carpenter, 2017; Rheingold, 2012). People on the internet need to assess online tools' reliability and legitimacy because of electronic media shortcomings. However, Stanford studies found that youngsters frequently rely on unyielding websites from large web search engines and deceptive websites (Krutka \& Carpenter, 2017; Wineburg \& McGrew, 2016).

Countries like New Zealand and Australia seek to foster the importance of digital citizenship rights and obligations and attempt to make it part of government policy (Manzuoli et al., 2019). It shows that awareness of digital citizenship as a fundamental human right is critical to strengthening (Sullivan, 2016; Simsek \& Simsek, 2013; Gorman, 2015). This initiative is backed by experts such as Area \& Ribeiro (2012). They demonstrate that modern literacy is an individual right and a necessary condition for social and democratic growth in 21st-century society.

Responsible digital people should differentiate between credible sources, ensure the reliability of information through websites and digital accounts, contextualize storytelling, and understand perspective. Digital citizens have a particular obligation to society, mainly when producing or publishing works such as writing; students should be permitted (or not) to protect their jobs. Rights and obligations are often challenging to assess. By adhering to the concept of digital citizenship, most consumers will reap the advantages of digital technologies because they will recognize that there is a right in society only when there is a duty.

Computer skills are running computers and other technology for improving learning, efficiency, and success. These include accountability for the use of technology, ways of accessing the internet, social media network infrastructure, hardware and software equipment, and the use of technology as a communication device. Understanding how computers and software systems are designed for practical purposes (Martin \& Grudziecki, 2006).

Digital ethics is regarded as a norm or protocol for the use of technology. Digital people are using technology in a contextually relevant manner. Digital people do need to be mindful of the explicit and tacit laws for the use of technology. Ethical information is about identifying and evaluating sources, analyzing and synthesizing content, assessing the cause's credibility, ethically referencing, concentrating, and formulating research questions correctly and efficiently (Meyers, Gamst, \& Guarino, 2006).

People with strong digital ethics will shape an ethical and responsible digital society (Ribble, 2015). Individuals behaving as digital people demonstrate strong ethics and culture 
Vol. 10, No. 2, 2021, E-ISSN: 2226-6348 @ 2021 HRMARS

without affecting the well-being of the digital community. They comply with the virtual world's rules, norms, and values, which have been considered unspeakable (Hollandsworth, Dowdy, \& Donovan, 2011). Despite having different opinions from other digital users, they should connect and interact respectfully.

\section{Youth and Technology}

Youth and technology represent two traits that are generally associated with social media problems, both equally relevant categories. Given all the benefits, there are still some common effects for the modern era of technology. Anything can be readily accessed through the internet without borders (Tengku Mariam et al,2019). While it is clear that the online world plays a crucial role in day-to-day operations, the internet's influence might also lead to disruption and perhaps a benefit. Over the last few decades, young people have been the target most easily adjusted to the effects of technology enhancement and the improvements in that (Camacho, Minelli \& Grosseck, 2012).

Additionally, like Hargrove et al (2014) said, youngsters, reflect more on the social era than on the developmental level, which is the adjustment time between youth vulnerability and adult responsibility. Youth is seen as a fragile generation as well. This condition will impact their growth and the environment in which technology is evolving from the point of view of social media. In other words, young adults will be vulnerable to unhealthful Internet and social media activities that could lead to emotional distress. Richards, Caldwell \& Go (2015) stated that the psychological impact of cyberbullying and 'Facebook depression' on young people's media platforms are one of the main emotional and psychological concerns.

Erikson (1968) reported that the creation of socially identifiable personalities is an important part of the complexities of developmental psychology. He assumes that if teenagers able to recognize their multiple roles in the social context and relationships through "selfsimilarity and inner continuity," they can effectively develop their identities. When teenagers broaden the borders of healthy relationships and communities, they learn their rights and duties. Interpersonal interactions and social contexts play a vital role in establishing and preserving this identity (Adams \& Marshall, 1996; Erikson, 1968). However, the social experience of teenagers today is very different from that of previous generations. In specific, through smartphones, social networking platforms, short messaging networks, blogs, augmented reality, and websites, emerging media technologies create a new forum for teens to communicate and explore their identities.

With the presence and accessibility of numerous emerging technologies, it is important to figure out how students communicate in the modern world. Younger generations were born in the modern era to understand the scarcity of knowledge learning devices. They both grew up in the urban world and lived their lives as users of technology. It is also vital to discuss the effects of the modern age on the creation of teenage self-identity. 
DEVELOPMENT

Vol. 10, No. 2, 2021, E-ISSN: 2226-6348 @ 2021 HRMARS

\section{Methodology}

Data collection

A questionnaire used as the instrument for this study to measure undergraduates' knowledge about digital citizenship: the questionnaire contained 40 items on knowledge of digital citizenship. Items in the questionnaire were constructed based on the reading of previous literature reviews. The items measured on a five-point Likert scale such as (1: strongly disagree; 2: disagree; 3: neither agree nor disagree; 4: agree; 5 : strongly agree). The number of items and the questions is summarised in Table 1.

Data analysis

The data used in this study were analyzed using Statistical software. Data analysis involved three stages. The first stage was reliability analysis, which was performed for each variable to ensure the obtained data's reliability. Respondents ' demographic information for this research study has been descriptively analyzed as it is important to evaluate the frequency and percentage of respondents' demographic factors. The additional analysis involved exploratory factor analysis of the items to see how the items were used and classified according to the structure of certain factors (Hair, Anderson, Tatham, \& Black, 2010).

Analysis of reliability

Generally, it is essential to measure the reliability of a test and the ability of items in the instrument. Reliability is the accuracy and stability of the currency or marks of the measurement scale (Hair et al., 2010). According to Sekaran and Bougie (2009), the higher the value, the higher the alpha internal reliability. This study set the value of Cronbach's alpha coefficient at .70, as suggested by Babbie (2007), Hair et al. (2010), and Pallant (2010). The reliability of all items in this instrument was more than .70 (Table 2), indicating that the reliability of items built into the questionnaire was acceptable.

Factor analysis

Factor analysis is a statistical method used to analyze several variables' relationships and explain variables in certain latent factors (Chua, 2009; Hair et al., 2010). It is a statistical approach used to summarise the information found in the original number of variables to smaller dimensions or general nature. Factor analysis can group into two different approaches: exploratory factor analysis (EFA) and confirmatory factor analysis (CFA).

Exploratory factor analysis

EFA is described as summarising the interrelated variables. It is a procedure of reducing the number of variables that signify latent constructions and structural factors that underlie a set of variables (Chua, 2009; Hair et al.,2010). According to Child (1990), EFA is used to explore the structure of factors that may underline a set of variables studied without imposing any structure formed before conducting any further analysis. Through EFA, the number of constructs and structural factors underlying the variables studied can be identified. Structural factors can give rise to findings based on responses taken from a sample survey. This study assigned three constructs based on a question that had been built by the researcher.

Confirmatory factor analysis

CFA is a statistical technique used to verify the factor structure of the set of variables studied (Byrne, 2010; Hair et al., 2010). Analysis factor authentication helps the researcher check the 
assumptions (hypothesis) found in the relationships among the variables tested with loading factors that may or may not exist. (Byrne, 2010; Hair et al., 2010). The researchers used theoretical knowledge, empirical research, or both to arrive at the relationship between the priorities and then tested the hypothesis using statistical methods (Byrne, 2010; Hair et al., 2010). In order to build latent variables and observed variables, a measurement model was used. The measurement model is a model that defines the relationship between the observed variables with the latent variables. The latent variables are also known as factors or constructs, and the variables are known as indicators. Indicators were items (questions) used in the questionnaire to observe latent variables or constructs (Byrne, 2010; Hair et al., 2010). The resulting afterweighting measurement or analysis is called a loading factor.

\section{Instrument}

This study used a questionnaire as a research instrument, consisting of two parts, namely part $A$ and part B (Table 1). Part A contains the respondents' demographic information, while Section B covers information on the study variable, which is digital citizenship knowledge.

Table 1. Respondent Questionnaire Information

\begin{tabular}{llll}
\hline Part & Details & Construct & Number of Items \\
\hline A & Background of Respondent & Gender & 2 \\
& & Races & 6 \\
& & Types of digital use & 4 \\
& & Purpose of using digital tools & 6 \\
& & Hours of Digital Device Usage & 6 \\
B & Digital Citizenship Literacy & Rights and Responsibilities & 15 \\
& Knowledge & Knowledge Of Technology Usage & 15 \\
& & Ethics & 10 \\
\hline
\end{tabular}

Instrument Reliability

Table 2 shows the literacy knowledge element's reliability with Cronbach's Alpha value, which measures the variables' internal consistency. According to Babbie (2007), Cronbach's Alpha value is classified based on a reliability index classification where the $0.90-1.00$ value is very high, $0.70-$ 0.89 is high, $0.30-0.69$ is moderate, and $0.00-0.30$ is low. The analysis results showed that Cronbach's Alpha value was at a high and very high classification, which exceeded 0.80 . This study instrument has high reliability, according to Babbie's classification (2007).

Table 2. Reliability of Digital Citizenship Knowledge Literacy

\begin{tabular}{lllll}
\hline Variables & Sub Variables & Number of Items & $\begin{array}{l}\text { Alpha } \\
\text { Values }\end{array}$ & Cronbach \\
\hline Digital & Rights and Responsibilities & 15 & .788 \\
Citizenship & Knowledge Of Technology & 15 & .905 \\
Literacy & Usage & & \\
Knowledge & Ethics & 10 & .893 \\
\hline
\end{tabular}


Vol. 10, No. 2, 2021, E-ISSN: 2226-6348 @ 2021 HRMARS

\section{Results and Discussion}

Demography Respondent

Table 3 shows the respondent's distribution of backgrounds from undergraduates' students from Sultan Idris Education University, Tanjong Malim, Perak, Malaysia. In a total of 1000 students who participated, the number of females was 684 (68.4\%), while the rest were male. The majority of the respondents' races were Malay 62.6 (62.6\%) followed by Bumiputera Sabah 149 (14.9\%), Bumiputera Sarawak 98 (9.8\%), Indian 60 (6.0\%), Chinese 57 (5.7\%) and other races 10(1.0\%). Each respondent was selected from nine different faculties within the university. Most of the respondents used a smartphone to access the internet $(n=988,98.8 \%)$, besides the majority of $886(88.6 \%)$ respondents using digital devices for education. The highest respondents' daily internet use was around 8 to 10 hours $(n=253,25.3 \%)$.

Table 3. Respondent's Background

\begin{tabular}{llll}
\hline \multirow{2}{*}{ Gender } & Male & $\mathrm{N}$ & $\%$ \\
\cline { 2 - 3 } & Female & 316 & 31.6 \\
Race & Malay & 684 & 68.4 \\
& Indian & & \\
& Chinese & 626 & 62.6 \\
& Bumiputera Sabah & 60 & 6.0 \\
& Bumiputera Sarawak & 57 & 5.7 \\
& Others & 149 & 14.9 \\
& & 98 & 9.8 \\
& & 10 & 1.0
\end{tabular}

$\begin{array}{llll}\text { Faculty } & \text { Faculty of Language and Communication } & 154 & 15.4 \\ & \text { Faculty of Human Development } & 116 & 11.6 \\ & \text { Faculty of Human Sciences } & 151 & 15.1 \\ & \text { Faculty of art, creative computing industry } & 153 & 15.3 \\ & \text { Faculty of Science \& Mathematics } & 136 & 13.6 \\ & \text { Faculty of Sport Science } & 84 & 8.5 \\ & \text { Faculty of Technical and Vocational } & 58 & 5.8 \\ & \text { Faculty of Music \& Performance Arts } & 40 & 4.0 \\ & \text { Faculty of Economy } & 108 & 10.8 \\ \text { Types of } & \text { Smartphone } & & \\ \text { devices } & \text { Tablet } & 988 & 98.7 \\ \text { used } & \text { Laptop } & 91 & 9.1 \\ & \text { Desktop } & 873 & 87.3 \\ \text { Purpose } & \text { Edhers } & 149 & 14.9 \\ \text { of using a } & \text { Politics } & 92 & 9.2 \\ \text { digital } & \text { Entertainment } & & 88.6 \\ \text { device } & \text { Expertise } & 886 & 20.7 \\ & \text { Communication } & 207 & 82.7 \\ & & 827 & 36.3 \\ & \text { Comm } & 363 & 79.7\end{array}$


Vol. 10, No. 2, 2021, E-ISSN: 2226-6348 @ 2021 HRMARS

\begin{tabular}{|c|c|c|c|}
\hline & Others & 56 & 5.6 \\
\hline Hours of & $0<2$ & 10 & 1.0 \\
\hline Digital & $2-4$ & 61 & 6.1 \\
\hline Device & $4-6$ & 195 & 19.5 \\
\hline \multirow[t]{3}{*}{ Usage } & $6-8$ & 247 & 24.7 \\
\hline & $8-10$ & 253 & 25.3 \\
\hline & $>10$ & 234 & 23.4 \\
\hline
\end{tabular}

Exploratory Factor Analysis (EFA) for Digital Citizenship Knowledge Constructs

The result of Exploratory Factor Analysis (EFA) on the measuring instrument of digital citizenship knowledge explained that the anti-image correlation analysis procedures showed that the correlation value of the correlation was more significant than 0.5 , which indicated that the factor analysis could continue. Measurement adequacy of Kaiser-Meyer-Olkin sampling (KMO) and Bartlett's Test of Sphericity showed that the KMO value was 0.940 , while Bartlett's Test Sphericity was significant with its Chi-square value of 12842.792 at 780 degrees of freedom (Table 4).

Table 4. Suitability Test on the Use of Factor Analysis and Uniformity of KMO and Bartlett's Test Items towards Digital Citizenship Knowledge Variable

\begin{tabular}{|c|c|c|c|}
\hline Kaiser-Mey & r-Olkin & $\begin{array}{l}\text { The measure of Sampling } \\
\text { Adequacy }\end{array}$ & 0.949 \\
\hline \multirow{3}{*}{\multicolumn{2}{|c|}{$\begin{array}{l}\text { Bartlett's } \\
\text { Sphericity }\end{array}$}} & Approx. Chi-Square & 24037.474 \\
\hline & & $d f$ & 78 \\
\hline & & Sig. & 0.000 \\
\hline
\end{tabular}

Factor analysis is run by determining the number of factors extracted into three as categorized in the questionnaire. Table 5 shows the component matrix with varimax rotation. The varimax rotation method was performed to reduce the number of complex variables and increase the expected yield. The results found that the items P7, P11, and P17 had dropped for having an antiimage correlation matrix value of less than 0.5 . While the values of P16, P18, P19, P20, P21, P22, P23, P24, P25, P26, P27, P28, P29, and P30 were in component 1, which was knowledge of technology digital used. P1, P2, P3, P4, P5, P6, P8, P9, P10, P12. P13, P14, and P15 accumulated in component 2, which was knowledge of rights and responsibilities. P31, P32, P33, P34, P35, P36, P37, P38, P39, and P40 belonged to group 3, ethics knowledge. The values shown in Table 6 are the coefficient or the load factor for each item that tends to each accumulated factor. These values show the correlation factors.

Table 5. The digital Citizenship Knowledge Literacy scale items and the respective factor loadings.

\begin{tabular}{ll}
\hline Items & F1 \\
\hline Factor 1: Knowledge of Technology Used & \\
P16 I know how to use digital tools. & 0.555 \\
P18 I know how to access the internet. & 0.502 \\
P19 I know how to find information through the internet. & 0.513
\end{tabular}


Vol. 10, No. 2, 2021, E-ISSN: 2226-6348 @ 2021 HRMARS

$\begin{array}{ll}\text { P20 I have access to information on the internet. } & 0.701\end{array}$

P21 I know using social media applications. $\quad 0.702$

P22 I know digital literacy is a process of teaching and learning technology.

0.717

P23 I know there are various types of digital electronic tools. $\quad 0.643$

P24 I have knowledge of digital electronic hardware and software. $\quad 0.554$

P25 I know digital communication (e.g., email, SMS, social media, etc.) 0.638

P26 I know digital communication tools allow me to connect with 0.687 other people around the world.

$\begin{array}{ll}\text { P27 I know digital trading is an e-commerce transaction. } & 0.611\end{array}$

P28 I know how to find information on goods before making an online purchase.

P29 I know that buying and selling online can save time. 0.699

$\begin{array}{ll}\text { P30 I know how to use digital tools. } & 0.647\end{array}$

\section{Factor 2: Right and Responsibility}

P1 I know being a good digital user is the responsibility of a digital citizen.

P2 I know digital ethics encompasses digital rights and responsibilities.

I know that everyone has the right to use digital technology in privacy.

I know the rights and responsibilities of using digital technology are different.

P5 I have the right to use digital communication tools.

I am responsible for using the digital communication medium properly.

I am responsible for not sharing secrets on digital media platforms because they are not safe.

0.66

It is my responsibility to keep information secure from being hacked.

I know the use of digital tools needs to be balanced in everyday life.

I know the use of digital tools over time has led to gadget addictions.

P14 I know good digital citizens obey the rules.

I know being a good digital user is the responsibility of a digital citizen.

0.665

\section{Factor 3: Ethics}

P31 I know that spreading false information to other digital users is misconduct. 
Vol. 10, No. 2, 2021, E-ISSN: 2226-6348 @ 2021 HRMARS

P32 I know that threatening and embarrassing other digital users are an offense.

P33 I know that plagiarizing the work of other individuals on a digital site is misconduct.

P34 I know cyberbullying is illegal.

P35 I know surfing a digital site that contains pornographic elements is misbehavior.

0.733

P36 I know that downloading pirated computer software is illegal.

P37 I know that hacking a system and network is illegal.

0.746

P38 I know that stealing one's identity is illegal

P39 I know that having a fake digital information account is illegal.

0.658

Confirmatory Factor Analysis (CFA) for Digital Citizenship Knowledge Constructs

Exploratory Factor Analysis (EFA) had been carried out to accumulate items of the digital citizenship knowledge constructs. Confirmatory Factor Analysis (CFA) was conducted using AMOS 20 software to determine the first and second levels of the confirmatory factor analysis model of digital citizenship knowledge after the EFA process. Figure 1 shows the CFA model's first level for digital citizenship knowledge constructs that have not achieved good matching accuracy compared to the second CFA model after several items had been deleted in Figure 2.

Table 6: The model fits of CFA model of the Digital Citizenship Constructs

\begin{tabular}{lllllll}
\hline & $\mathrm{X}^{2}$ & $d f$ & GFI & CFI & TLI & RMSEA \\
\hline First stage & 4280.036 & 626 & .787 & .830 & .819 & .076 \\
Final model & 727.099 & 149 & .927 & .940 & .931 & .062 \\
\hline
\end{tabular}


INTERNATIONAL JOURNAL OF ACADEMIC RESEARCH IN PROGRESSIVE EDUCATION AND DEVELOPMENT

Vol. 10, No. 2, 2021, E-ISSN: 2226-6348 @ 2021 HRMARS

Figure 1. First Level Confirmatory Factor Analysis Model of Digital Citizenship Knowledge

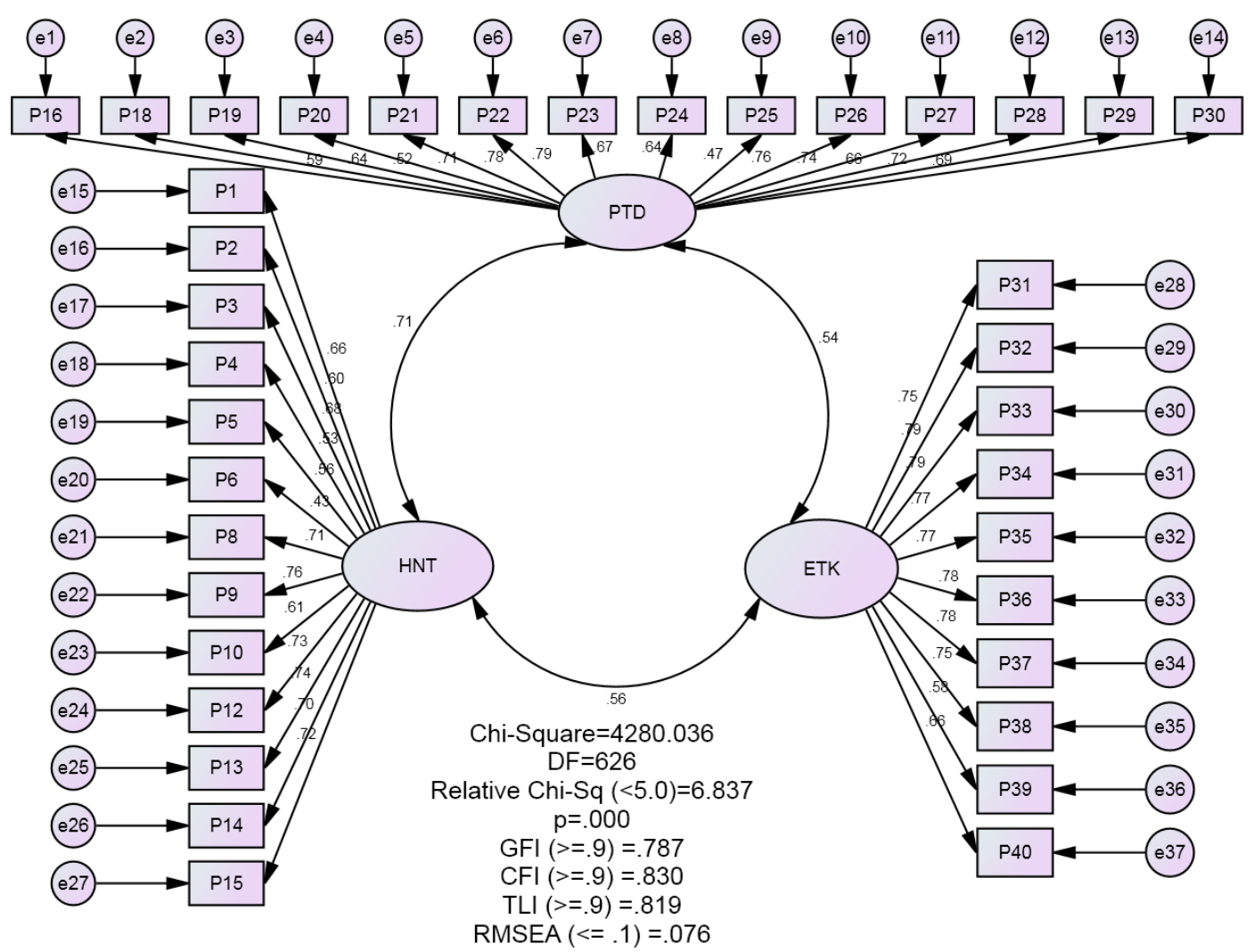


Figure 2. Final Model Confirmatory Factor Analysis Model of Digital Citizenship Knowledge

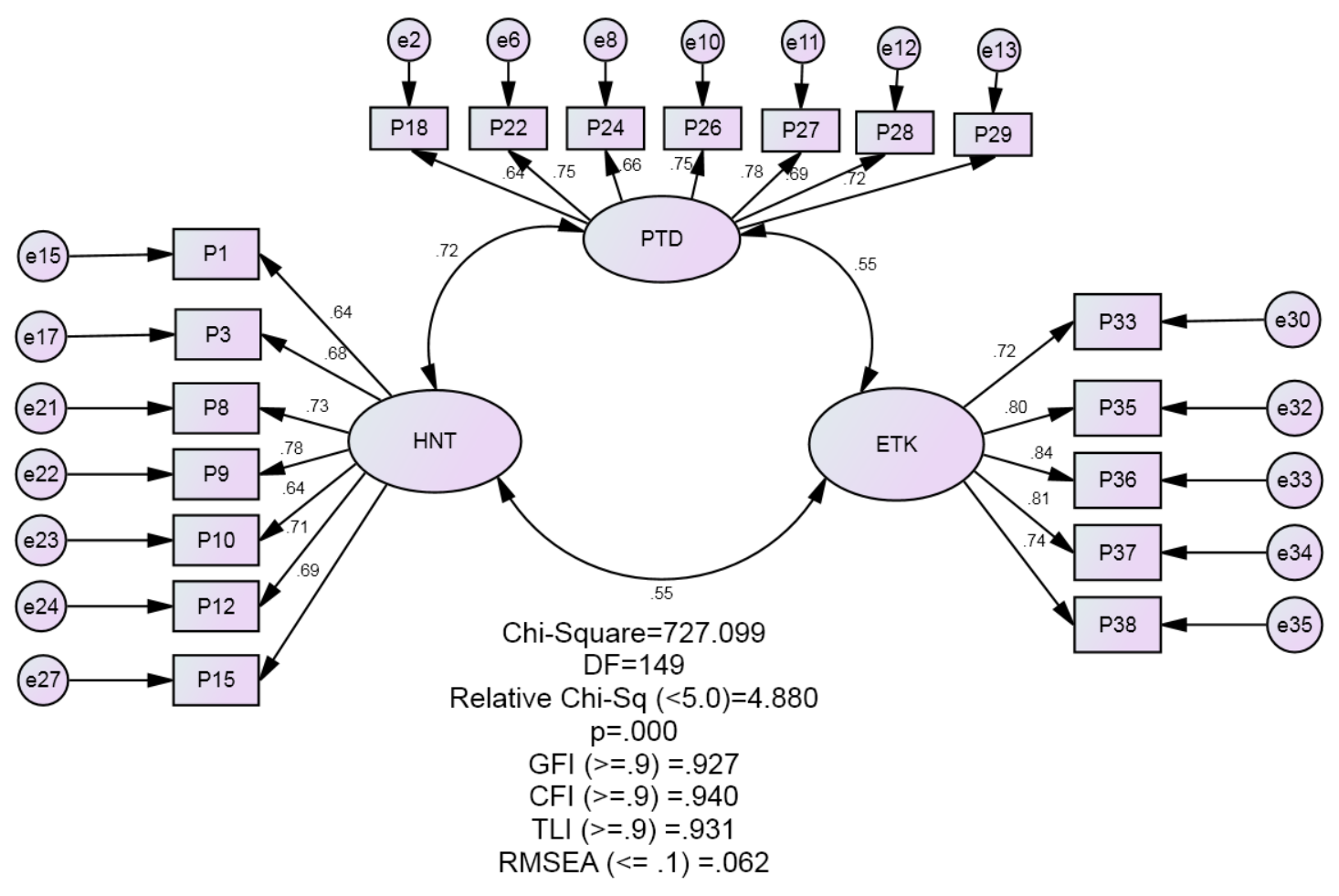

The model analyses in Figure 2 shows that the model formed has reached a good level of compatibility based on the determined indicators (CMIN=727.099, $\mathrm{DF}=149, \mathrm{CMIN} / \mathrm{DF}=4.880$, $\mathrm{p}=.000, \mathrm{CFI}=.940, \mathrm{GFI}=.927, \mathrm{TLI}=.931, \mathrm{RMSEA}=.062)$. Therefore, the second stage items (P18, P22, P24, P26, P27, P28, P29, P1, P3, P8, P9, P10, P12, P15, P33, P35, P36, P37, and P38)) of confirmatory factor analysis model of digital citizenship knowledge can be used in measuring the level of digital citizenship as well as in constructing a structural equation model of digital citizenship literacy among undergraduates in Malaysia according to the conditions set forth by Hair (2006) and Fornell and Larcker (1981).

\section{Theoretical Implication}

The digital citizenship knowledge among higher institution students in Malaysia has important implications to educate students to become informed and active digital citizens, suggesting the technology used, rights and responsibilities and ethics as important elements. The study revealed that while some elements of digital citizenship such as digital skills can be relatively easy to achieve, other than related to rights and responsibilities when use digital technology need to be achieved as well. The results also informed that certain elements of digital citizenship are very 
important to provide a curricular of digital citizenship in school. Digital citizenship is not static, stable, and/or fixed but a dynamic, flexible, contextual and a multi-layered concept that is interwoven with individuals' everyday online activities. Throughout western history, the development of the concept of citizenship has been constructed as an individual relationship with the nation state. Lawson and Scott (as cited by (Rapoport, 2010) stated that obedience and loyalty to the state, common identity, equality and tolerance have been the overarching principles of citizenship. Nevertheless, modernization and globalization discourses have profoundly challenged the traditional idea of citizenship. Among the changes, there includes the impact of social movements that seek to achieve more inclusive citizenship with regards to gender, ethnic, and social class recognition. Subsequently, the globalization process has led to another perspective of seeing citizenship that is citizenship in a digital world. It widely-known that the internet promotes education beyond geographical and time boundaries (Harsasi, 2015; Kuntoro \& Al-Hawamdeh, 2003). Rapidly changing of communities, knowledge, education, and advanced technologies make citizenship has no considered from the perspective of physical location, but extends as membership in online and global environments. Most people are becoming digital citizens, which relies on interacting digitally (Akcil, 2018). A digital citizen is a person who uses the internet regularly and effectively as well as knows and utilizes their rights and responsibilities virtually (Thomas, 2018). Accordingly, growing technological determination give affects how future citizenship will be perceived and implemented. Regarding the challenge, technological developments may provide a means to exercise the use of citizens' rights and obligations (Simsek \& Simsek, 2013). Therefore, digital citizenship has emerged as an essential concept during the last few decades for building a framework of using technology effectively (Choi, 2015; Emejulu \& McGregor, 2019; Ribble, 2015). Learning culture has moved forward from face-to-face to virtual learning. It requires proactive actions from educators to develop citizenship competencies that contain values, attitudes, knowledge, skills, and critical understanding (Kim \& Choi, 2018). Choi's view that digital citizenship is not only using technology wisely but also a concept of promoting democratic citizenship in the internet age. Digital citizenship and digital literacy cannot be separated. Both lead to new literacy in the form of Web 2.0, online participation, citizenship rights, technological capabilities, internet, social networks, values, norms, being informed, critical attitude, and digital divide. They are key issues in the interaction of new literacies and digital citizenship. The new literacy is a tendency that will lead to the development of digital citizenship to provide opportunities to actualize active and participatory citizenship. Understandings of digital citizenship literacy knowledge among higher education students has no doubt contribute to prepare a digital citizen as well promoting on how digital citizenship should be taught. The presented findings of digital citizenship literacy knowledge in Malaysia is a start-up, and as such cannot be ideal; but it is believed has the potential to contribute theoretically in developing more advanced and higher quality understandings of digital citizenship. 


\section{Conclusion}

The EFA and CFA results showed that convergent validity had been achieved in this study. The EFA results showed that three components of digital citizenship literacy knowledge were generated: the knowledge of rights and responsibilities, knowledge of digital technology usage, and knowledge of ethics. Besides, several items had been dropped out of 40 original items constructed by the researchers, 19 items accepted to get a pleasing matching index, and 21 more items dropped through this analysis. The corresponding values were following the determined conditions. Overall, the digital citizenship literacy knowledge model generated from this CFA process can be used to measure the level of digital citizenship knowledge of undergraduates' students. The development of digital citizenship literacy knowledge instruments through the CFA process model among undergraduates allows other researchers to test this model for other respondent demography types.

\section{Acknowledgements}

This study had conducted with the help of a Fundamental Research Grant (FRGS 2019-0026-10602). Thanks to the Universiti Pendidikan Sultan Idris, Malaysia, for the research funds and to the respondents who participated in this research study.

\section{Reference}

Abdulrahman, A.-Z. (2015). Toward Digital Citizenship: Examining Factors Affecting Participation and Involvement in the Internet Society among Higher Education Students. International Education Studies, 8(12), 203-217.

Adams, G. R., \& Marshall, S. L. (1996). A developmental social psychology of identity: Understanding the person in context. Journal of Adolescence, 19(5), 429-442.

Afinde, O. (2016). Pengetahuan, Kemahiran Dan Amalan Guru Membina Item Kemahiran Berfikir Aras Tinggi (KBAT) dalam Instrumen Pentaksiran Pembelajaran. Universiti Tun Hussein Onn Malaysia.

Akcil, U. (2018). "The Use of Mobile Learning for Visually Impaired Learners School in Tolerance Education Contents." Quality and Quantity 52: 969-82.

Alcaide-Muñoz, L., Rodríguez-Bolívar, M., Cobo, M., \& Herrera-Viedma, E. (2017). Analysing the scientific evolution of e-government using a science mapping approach. Government Information Quarterly, 34(3), 545-555.

Area, M., \& Ribeiro, M. (2012). From Solid to Liquid: New Literacies to the Cultural Changes of Web 2.0. Comunicar, 38, 13-20.

Babbie, E. (2007). The practice of social research. Belmont, California: Thomson Wadsworth.

Biladeau, S. (2009). Technology and Diversity: Perceptions of Idaho's Digital Natives. Teacher Librarian, 36, 1-3.

Bittman, M., Rutherford, L., Brown, J., \& Unsworth, L. (2011). Digital Natives? New and Old Media and Children's Outcomes. Australian Journal of Education, 55, 161-175.

Bouhnik, D., \& Deshen, M. (2013). Unethical Behavior of Youth in the Internet Environment. The International Journal of Technology, Knowledge, and Society, 9, 109-124.

Byrne, B. (2010). Structural equation model with AMOS: Basic concepts, applications, and programming (2nd Edition). Mahwah, N.J: Mahwah, N.J: Lawrance Erlbaum Associates, Inc. 
INTERNATIONAL JOURNAL OF ACADEMIC RESEARCH IN PROGRESSIVE EDUCATION AND

DEVELOPMENT

Vol. 10, No. 2, 2021, E-ISSN: $2226-6348$ @ 2021 HRMARS

Camacho, M., Minelli, J., \& Grosseck, G. (2012). Self and identity: raising undergraduate students' awareness on their digital footprints. Procedia - Social and Behavioral Sciences, 46, 31763181.

Child, D. (1990). The essentials of factor analysis (2nd ed.). Cassell Educational.

Choi, M. (2015). "Development of a Scale to Measure Digital Citizenship among Young Adults for Democratic Citizenship Education." The Ohio State University.

Chua, Y. P. (2009). Statistik penyelidikan lanjutan ujian regresi, analisis factor dan analisis SEM. Kuala Lumpur: Mc Graw-Hill.

Curran. (2012). iCitizen: Are you a socially responsible digital citizen? In International Society for Technology in Education.

Darwin, P. . (2003). The Concept of Knowledge and How To Measure It. Journal of Intellectual Capital, 4(1), 100-113.

Emejulu, A., and McGregor, C. (2019). "Towards a Radical Digital Citizenship in Digital Education." Critical Studies in Education 60(1): 131-47.

Erikson, E. (1968). Identity: Youth and crisis. Norton \& Co.

Fornel, C., \& Larcker, D. (1981). Evaluating structural equation models with unobservable variables and measurement error. Journal of Marketing Research, 18(1), 39-50.

Gazi, Z. A. (2016). Internalization of digital citizenship for the future of all levels of education. Education and Science, 41(186), 137-148.

Ghamrawi, N. A. (2018). Schooling for Digital Citizens. Open Journal of Leadership, 7, 209-224.

Gorman, G. (2015). What's missing in the digital world? Access, digital literacy and digital citizenship. Online Information Review, 39(2). Retrieved from https://www.emeraldinsight.com/doi/full/10.1108/OIR-02-\%0A2015-0053

Hair, J., Black, B., Babin, B., Anderson, R., \& Tatham, R. (2010). Multivariate data analysis: A global perspective. New Jersey: Pearson Education Inc.

Hair, J. F., Black, W. C., Babin, B. J., Anderson, R. E., \& Tatham, R. L. (2006). Multivariate data analysis (6th.ed). New Jersey: Upper Saddle River.

Hargrove, A., Pells, K., Boyden, J., \& Dornan, P. (2014). Youth vulnerabilities in life course transitions. UNDP Human Development Reports. Retrieved from http://hdr.undp.org/en/content/youth-vulnerabilities-life-course-transitions

Harsasi, M. (2015). "The Use of Open Educational Resources in Online Learning: A Study of Students' Perception." Turkish Online Journal of Distance Education 16(3): 74-87.

Hollandsworth, R., Dowdy, L., \& Donovan, J. (2011). Digital citizenship in K-12: It takes a village. TechTrends, 55(4), 37-47.

Ibrahim, G. (1995). Knowledge, attitude and practice the three pillars of excellence and wisdom: a place in the medical profession. Eastern Mediterranean Health Journal, 1(1), 8-16.

Isman, A., \& Gungoren, O. C. (2014). Digital citizenship. The Turkish Online Journal of Educational Technology, 13(1), 73-77.

James, C., Davis, K., Flores, A., Francis, J. M., Pettingill, L., Rundle, M., \& Garnder, H. (2010). Young People, Ethics, and the New Digital Media , 2, 215-284. Contemporary Readings in Law and Social Justice, 2, 215-284.

Krutka, D. G., \& Carpenter, J. P. (2017). Digital Citizenship in the Classroom. Journal of the Department of Supervision and Curriculum Development, (November), 50-55. 
Manzuoli, C. H., Sánchez, A. V., \& Bedoya, E. D. (2019). Digital Citizenship: A Theoretical Review of the Concept and Trends. Turkish Online Journal of Educational Technology - TOJET, 18(2), 10-18.

Martin, A., \& Grudziecki, J. (2006). DigEuLit: Concepts and tools for digital literacy development. Innovation in Teaching and Learning in Information and Computer Science, 5(4).

Meyers, L. S., Gamst, G., \& Guarino, A. J. (2006). Applied Multivariate Research: Design and Interpretation. SAGE Publications.

Mossberger, K., Tolbert, C. J., \& McNeal, R. S. (2011). Digital Citizenship: The Internet, Society, and Participation. Cambridge; MA and London: The MIT Press.

Nor Aslamiah, A. (2015). Digital Citizens: Adab dan Tanggungjawab. Dimensikoop, (47), 11-20. Retrieved from http://www.mkm.edu.my/images/Awam/Penerbitan/Dimensi_Koop/Dimensi_Koop47/di gital-citizens-adab-dan-tanggungjawab.pdf

Ohler, J. (2011). Digital citizenship means character education for the digital age. Kappa Delta Pi Record, 47, 25-27.

Orth, D., \& Chen, E. (2013). The Strategy for Digital Citizenship: Guiding Our Children in a Digital World. National Association of Independent Schools, 72, 56-63.

Oxley, C. (2011). Digital citizenship: Developing an ethical and responsible online culture. Access, 25(3), 5-9.

Pallant, J. (2010). A step by step guide to data analysis using the SPSS Program (4th. ed.). Australia: Mc Graw-Hill.

Rapoport, A. (2010). "We Cannot Teach What We Don't Know: Indiana Teachers Talk about Global Citizenship Education." Education, Citizenship and Social Justice 5(3): 179-90.

Rheingold, H. (2012). Net Smart: How to thrive online. Cambridge, MA: MIT Press.

Ribble, M. (2015). Digital Citizenship in Schools: Nine Elements All Students Should Know (Third Edition). Washington DC: International Society for Technology in Education.

Ribble, M., \& Bailey, G. (2007). Digital Citizenship in Schools. Washington DC: ISTE.

Richards, D., Caldwell, P. H., \& Go, H. (2015). Impact of social media on the health of children and young people. Journal of Paediatrics and Child Health, 51(12), 1152-1157.

Richards, R. (2010). Digital citizenship and web 2.0 tools. MERLOT Journal of Online Learning and Teaching, 6(2), 516-522.

Richmond, J. M., \& Morgan, R. F. (1977). A national survey of the environment knowledge \& attitudes of fifth year pupils in England University. England: Information Reference Centre The Ohio State.

Sampedro, V., Sánchez, J., \& Poletti, M. (2013). Ciudadanía y tecnopolítica electoral. Ideales y límites burocráticos a la participación digital. Co-Herencia, 10(18), 105-136.

Searson, M., Hancock, M., Soheil, N., \& Shepherd, G. (2015). Digital citizenship within global contexts. Education and Information Technologies, 20(4), 729-741.

Sekaran, U., \& Bougie, R. (2009). Research methods for business: A skill-building approach (Fifth). United Kingdom: John Wiley \& Sons.

Shal, T., El Kibbi, I., \& Ghamrawi, N. A. (2018). Principals' Differentiated Learning through Social Media: Practices and Obstacles. International Journal of Education and Applied Research, 8, 19-29. 
Simsek, E., \& Simsek, A. (2013). New literacies for digital citizenship. Contemporary Educational Technology, 4(2), 126-137.

Sullivan, C. (2016). Digital citizenship and the right to digital identity under international law. Computer Law \& Security Review, 32(3), 474-481.

Tan, T. (2011). Educating Digital Citizens. Leadership, 41, 30-32.

Thomas, S. N. (2018). "Promoting Digital Citizenship in First-Year Students: Framing Information Literacy as a Tool to Help Peers." College and Undergraduate Libraries 25(1): 52-64.

VanFossen, P. J., \& Berson, M. J. (2008). Civic literacy in a digital age. Contemporary Issues in Technology and Teacher Education, 8(2), 122-124.

Wineburg, S., \& McGrew, S. (2016). Why students can't Google their way to the truth 